\title{
坐位手術における空気栓塞
}

超音波断層心蔵モニターを用いて

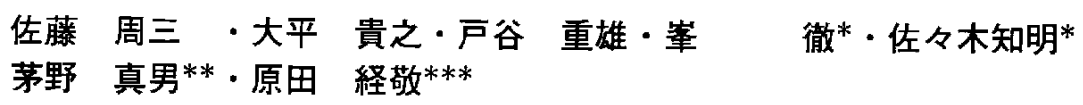

\section{Air Embolism during Neurosurgical Operations in the Sitting Position}

Efficacy of Real-Time Two-Dimensional Echocardiography

\author{
Shuzo Sato, Takayuki OHIRA, Shigeo ToYa, Tohru MINE*, Tomoaki Sasaki*, \\ Masao CHINo** and Tsunetaka HARADA*** \\ Department of Neurosurgery, Keio University, Tokyo; Departments of *Neurosurgery, **Cardiovascular \\ Disease and ***Clinical Laboratories, Ashikaga Red Cross Hospital, Ashikaga
}

\begin{abstract}
When a sitting operation is performed, early detection and prevention of air embolism are important. Air flow into the right heart system was monitored by a real-time two-dimensional cchocardiograph in combination with a video-recorder. The heart was observed from the apical four chamber view by a ditector placed under the xiphisternum and directed towards the base of heart. The echocardiography showed two types of air flow; one was the single-bubble type in which several bubbles flowed from the right atrium to the right ventricle, and the other was the stormy-bubble type in which a great number of air bubbles flowed en masse. The single-bubble type was observed during surgery involving the skin, muscle, or bone, and the air flow in this type could be interrupted by electrocoagulation, bone wax, etc. The stormy-bubble type was noted during surgery involving the muscle or dura mater. The air flow from the dura mater was most frequently observed. Retroflexion of the dura mater and then electrocoagulation would be required to prevent the air flow from the cut end of the dura mater. If electrocoagulation does not control the air flow from the cut end of the muscle, massive muscle suture by thick threads could prevent the air flow. Air flow into the right heart system in a sitting operation was more frequent than has previously been believed, and a small amount of air flow was noted even during minor surgery. Therefore, application of a sitting operation should be carefully undertaken.

Ultrasonic tomographic monitoring of the heart was useful in the early detection of air embolism because of its non-invasive technique and its high sensitivity.
\end{abstract}

Key words: air embolism, sitting operation, echocardiography

\section{I はじめに}

後頭蓋窝疾患や頸䯣病変に対しての坐位手術は，術野の 確保，出血した血液の排除という点で有用であるが，むと も恐万しい合併症である空気栓塞の発生率は平均 $20 \%{ }^{18)}$, ときには50\% と高頻度の報告がなさ扎ている。この空気 栓塞は，後頭蓋窩疾患の手術に続発するだけではなく，下
垂体への transsphenoidal approach ${ }^{15}$ の際や，頭部固定器 ○ had pin 部位加らの空気流入による発生例》も報告され ている，空気栓塞は pulmonary edema を発生させ4,112，致 命的な事態を引き起こす可能性が大である。坐位手術にお ける空気栓塞の問題は，従来から主として術中管理という 点で，麻酔科的立場で論ぜられ，空気栓塞の早期発見とそ の処置について検討されてきた。今回，我々は脳神経外科

\section{慶応義塾大学脳神経外科 *足利赤十字病院脳神経外科 **同偱環器科 ***同中央検查部}

Request reprints to: S. Sato, M.D., Department of Neurosurgery, Keio University, 35 Shinano-machi, Shinjuku-ku, Tokyo 160.

受稿 1981 年 9 月 8 日 受理 1982 年 6 月 23 日 


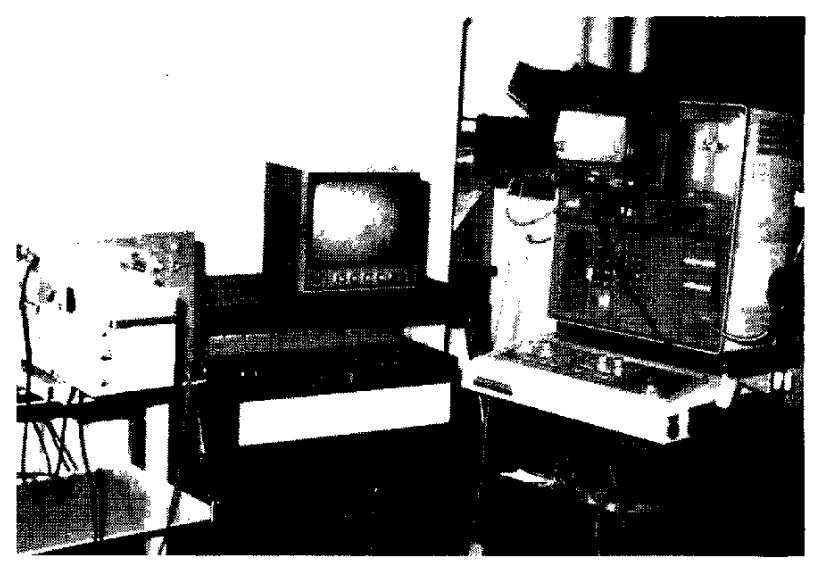

Fig. 1 Toshiba real-time two-dimensional echocardiography (SSH-11A).

的立場より, real time two dimensional echocardiography 老用いて，できるだけ早く空気流入を発見し，空気の流入 部位，流入量上手術操作との関係をみきわわた上で，士 ばやく空気栓塞の防止を行うことに成功したので報告す る.

\section{II 対象と方法}

対象は，坐位をた注側卧位手術を行った後頭葉動静脈奇

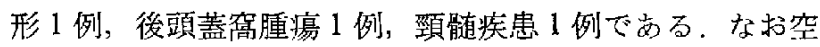
気の流入がみられた場合は，術前に心膛内に挿入留置した スワンガンッカテーテルより空気の吸引を試み，このスワ ンガンッカテーテルを用いて, 術後に発生しらる肺水腫に 対して対処した。

流入した a ir bubble の発見は，東芝電子走查形超音波 診断装置 SSH-11A 老用いて, real time two dimensional echocardiography と videorecorder 併用し検討を加えた (Fig. 1). Air bubble の観察は心葴内で行 起下ょり心基部にプローベを向けを apical four chamber view 法を用いた（Fig．2)，個体差によるエコー上のアーチ ファクトを除くために，手術前に術中と同様の体位を患者 にとらせ，プローベ接触部位にマーキングを行った。手術 中は，空気の流入が予測されるような手術操作を行らとき は, 連続的に real time two dimensional echocardiography によるモニタリング（Fig.3）と，videorecorderによる連続 記録を行った。また術前，右肘静脈よりスワンガンツカテ ーテルを挿入し，心拍出量，肺動脈圧，右房内庄，中心静 脈圧老測定し，肺血管抵抗，全身血管抵抗を計算し，術後 の全身管理のためのコントロール值死求めた。これは，空 気栓塞発生後に発症しらる肺水腫の際の全身管理に備える
Apical four chamber view
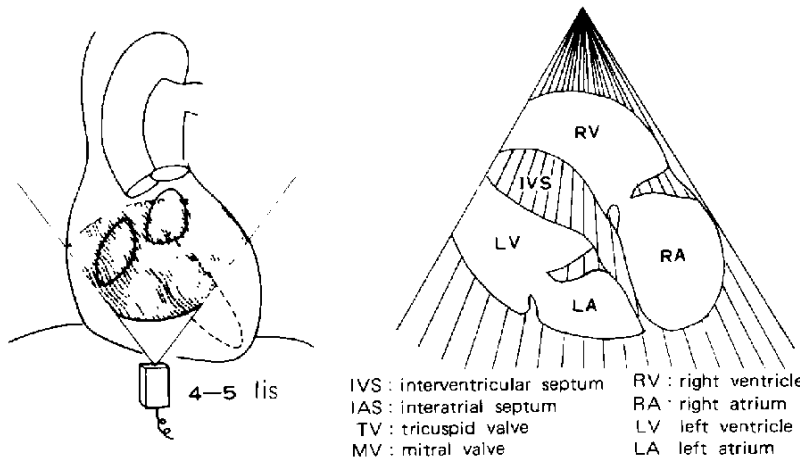

Fig. 2 Apical four chamber view.

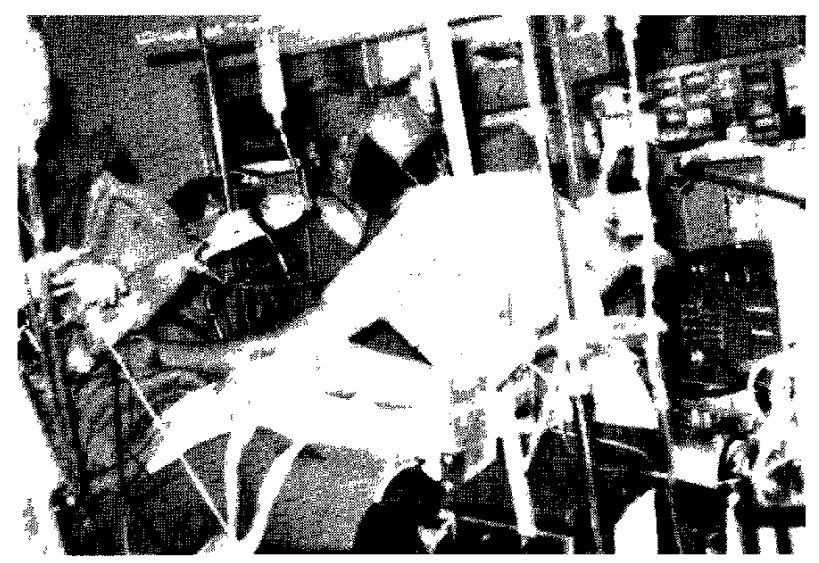

Fig. 3 Monitoring of air embolism by real-time twodimensional echocardiography in the sitting position.

ためである。前述の测定值を得たのち，スワンガンツカテ 一テルの先端を右室流出路に留置し, 術中 echocardiographyにて空気流入がみられた場合は，スワンガンッカテー テルより空気の吸引老試みた。

\section{III 結 果}

術前のコントロールの军真や，術中，空気流入がみられ ないとき，また空気流入が-分にコントロールされている ときには，有下に右房，上方江右室，中央に心房中隔，心 窒中隔が位置し，弁や心筋，心房中隔，心室中隔が，心拍 動に一致して動的に動いているのが観察された（Fig．4）。 空気流入時の心エコーの検討から，空気流入の型には，右 房加在室へかけて 1 数個以内の air bubble の流入の みるれる single bubble type (Fig. 5) と, 大量の air bubble が一塊となって流入寸る stormy bubble type (Fig. 6)とが 観察された，Fig. 5，6のごとく静的な写真でみると，air bubble $の$ 同定は若干難しいが，実際のテレビモニターでは 


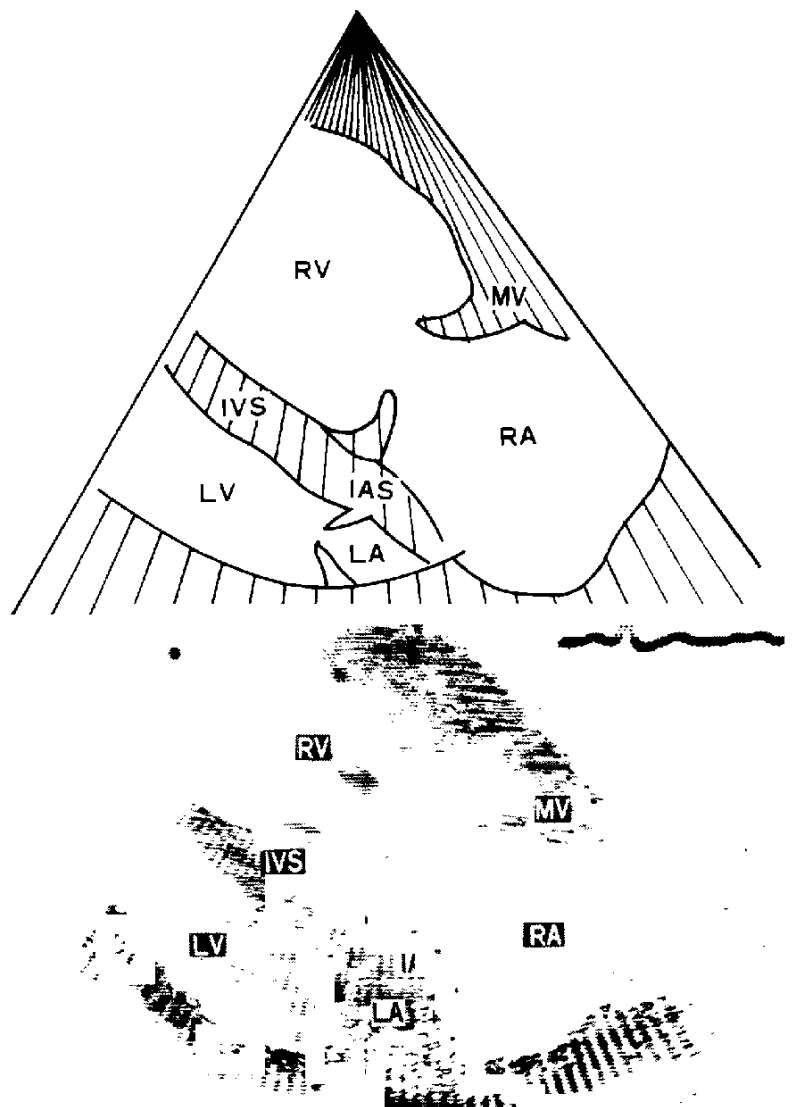

IVS: interventricular septum RV: right ventricle IAS : interatrial septum RA: right atrium TV: tricuspid valve LV: left ventricle MV : mitral valve LA : left atrium

Fig. 4 Preoperative echocardiogram.

air bubbleが明るい小粒子となって，右心房から右心室へ渦 状に移動していくため，その同定は比較的容易であった。

\section{<手術操作と空気流入の関係>}

皮虐切開：Fig. 5 のごとく, single bubble type $の$ air bubbleが，皮切開始とともに一過性に観察された。むし連 続的流入を認为た場合は，創周围の皮膚の庄迫や皮膚クリ ップの装着で, air bubble の流入は停止した。

筋膜, 笳肉切開：数個の air bubble の流入がみられる single bubble typeを示すこともあったが，大量のair bubble が一塊となって流入寸る stormy bubble type を示す場 合もあった. Single bubble type を示すときには，筋肉電気 凝固や開創器による筋肉圧排によって，air bubble の流入 をコントロールできた。しかし stormy bubble type t示し た場合は，電気凝固のみで法 air bubbleの流入をコントロ ールすることは難しく，数回にわたる筋肉の massive な結 禁によって，初めて air bubbleの流入を防止できた。なお
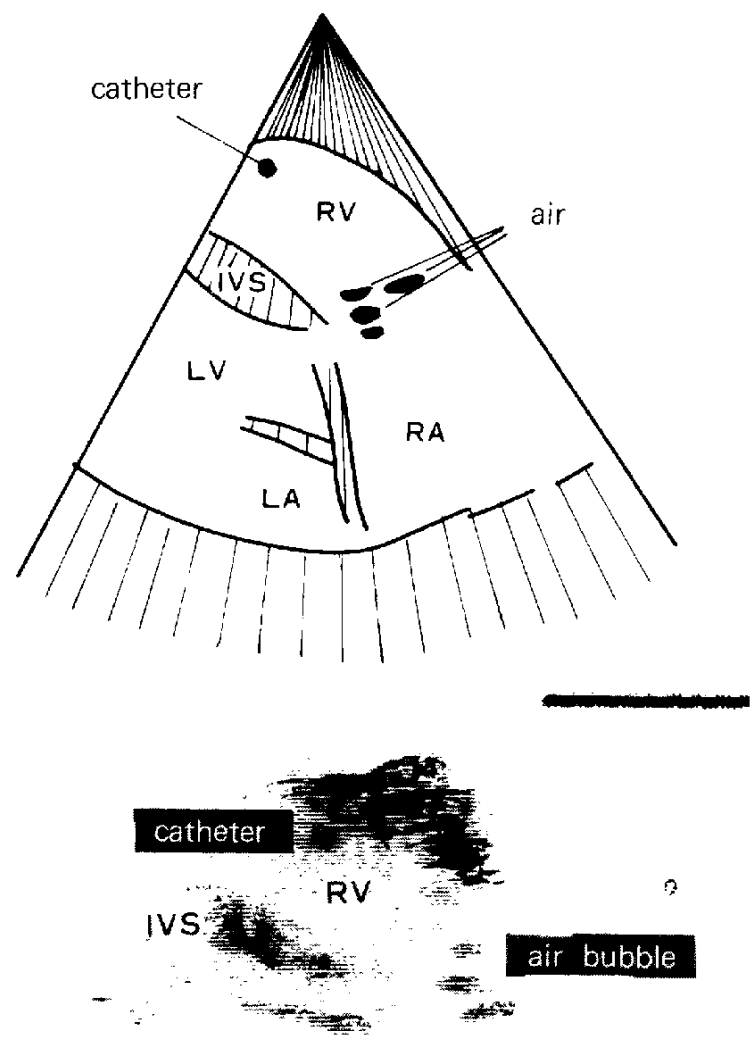

RA

LV

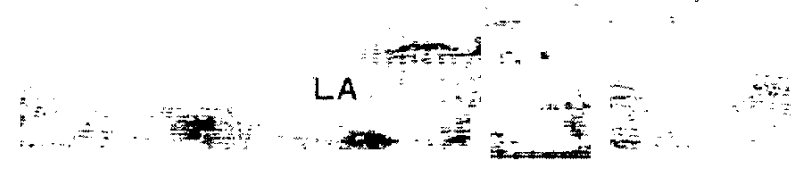

Fig. 5 Single bubble type echocardiogram.

筋肉を骨から剝離する際にも空気流入が観察された。

開頭, 頭蓋骨切開 : Air bubble が断続的に入ってくる single bubble typeを示すことが多かった．空気流入箇所法 骨表面や骨断端であり，比較的容易に同定できたため，骨 万ら塗布や，電気凝固に上り a ir bubbleの流入比較的簡 単に防止することができた。

硬膜切開：Air bubble の流入が各手術操作の中でもすっ とも多くみられ，特に後頭下開頭の際にこの傾向が強かっ た，右房加右室へ向って多数の air bubble吕一塊とな。 て流入する典型的な stormy bubble type を示した．硬膜切 開後に持続的な空気の流入がみられたが，その流入部位が 明確に同定できないとき，硬膜切開断端部に wct cotton strips を貼布し，上加ら生食水索かけて些気の流入を防ぐ試 みを行ったが，空気流入量がやや減るのみで，依然上して 多量の空気流入が続いているのが観察されることもあっ た。この場合，硬膜断端の電気凝固と硬膜反転汇より，air 


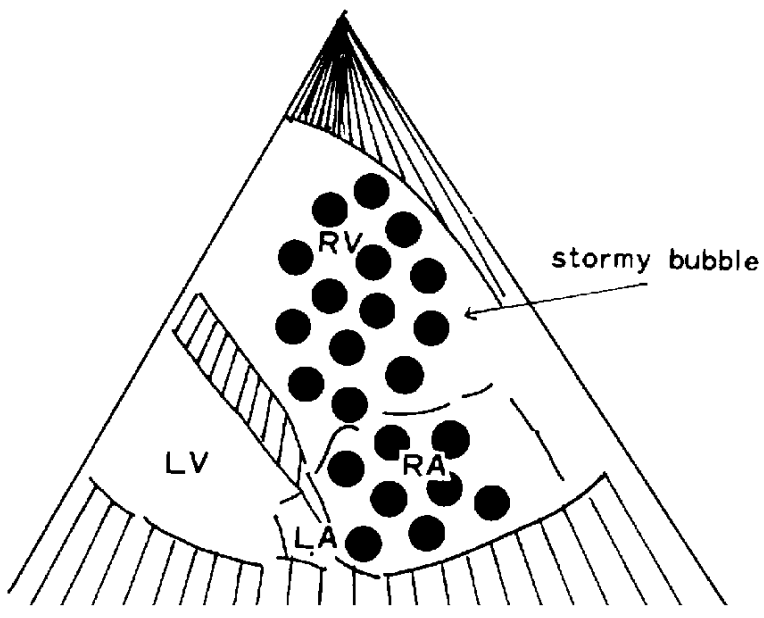

n $1 \%$

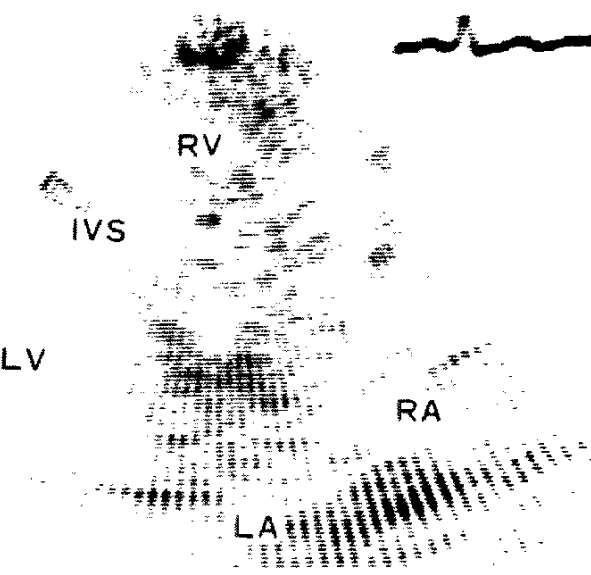

Fig. 6 Stormy bubble type echocardiogram.

bubbleの流入を停止させることができたが，後者の方法が 有效であった。

Brain lesion の剔出，脳内病変の手術操作中には single bubble type 空気の流入をみることはあったが，絪内の手 術操作部位がはっきりとわかっているため，電気凝固によ り容易に air bubbleの流入はコントロールされえた。

術中空気流入を認めた場合恃，術前加ら心腔内人留置し て扣いたスワンガンツカテーテルを用いて空気の玫引を 行らことはもらろんであるが，連続的にみられる stormy bubble typeでは，効果はほとんど期待できなかった．

\section{IV 考察}

従来 air embolism の早期診断の方法として，食道聴診 器11,17), Doppler ultrasonic detecter ${ }^{93}$, 終末呼吸気炭酸 ス濃度 (end-tidal $\left.\mathrm{CO}_{2}, \mathrm{~F}_{\mathrm{E}} \mathrm{CO}_{2}\right)^{2)}$ ，心電図の変化，中心静

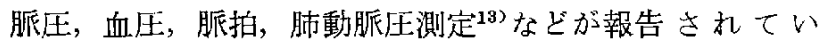
る、Englishら
は, (1) precordial Doppler ultrasound, (2) pulmonary artery pressure の上昇，(3) $\mathrm{F}_{\mathbf{E}} \mathrm{CO}_{2}$ の低下の顺であるとしている.

しか Marshall $ら^{10)}$ によれば, pulmonary aretery pressure がもっとも感度が良いとし, Philip 5 ${ }^{16)}$ は Doppler ultrasound 方もっとも sensitivity が高いとしており，意見の一 致をみていない，しかしこれらのモニタリングの多くは， 空気烃塞のための心肺循環動態の二次的変化老とらえてい るものであり，術中操作と空気流入の関係を，時間的执よ び量的なものとして観察したものではなかった. Doppler ultrasound は，1968年に Maroon ら ${ }^{9}$ が実用に供して以来 広く使用さ扎てきたが，これ空気流入による心音の変化 家いかに早くとらえるかとい5方法で，流入量を客観的に 把握したり，手術操作との関連索険討するのには不一分な ものであった。これらの不備な点を解決するため，我々は real time two dimensional echocardiography 孝用いて心臟 内の air bubble の発見在行った，超音波心臟断嘼法の基

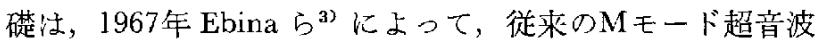
心獩断層法に代って，極近接水浸法を用いた高解像力の機 峨的走查法が開発されることによりつくられた。その後, 高速度走査法の発展により real time の観察が可能となり， 比較的最近になって実用化した。我々はこの心臓内断層法 の real time とい5特性を生加し，心臓内の air bubble の 検出に応用してみたが，従来のモ二ター上比べても感知性 能は非常に高く，実験的にす，動的なごく小さい single air bubbleでも検出可能であった，坐位手術にてair bubble が 流入した場合，約 2 秒で心滾内に達するため，この real time の特性を用いることによって，air bubble をただちに 検知寸ることができ，手術操作と空気流入レの関係が容易 に把握できた。このため，すばやく劦気流入を防止する操 作を行らことができた。

坐位手術に扔ける空気流入は，些細な手術操作で毛空気 流入が認められたが，従来の報告でも，右房と open vessel の較差が存在すれば空気は必ず流入すると報告されてい $ð^{12,15)}$ ，今回の我々の経験です，この較差が存在すれ将， 後頭蓋窩病変や頸䯣疾患に対寸る側卧位手術でも空気が流 入することがわかった。

空気流入の型には, single bubble type 上, 大量の空気の 流入のみられる stormy bubble type とが観察され， single bubble typeには，持続的な流入を示子型と，一過性の流入 を示す2つの型が多られた．Table l に手術操作と空気流 入の型の関係，およびそれに対処方心゙き手術手技を示し た. Single bubble type の空気流入がみられるのは, 皮膚, 筋肉，骨表面队骨断端，脑病変の手術操作中であるが，一 時的なものであれば特に処置は不用で，自然に空気流入の

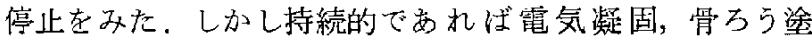


Table 1 The relationship of air embolisn and operative procedure

\begin{tabular}{|c|c|c|c|}
\hline & Type & Operation area & Operative treatmenl \\
\hline \multirow{2}{*}{$\begin{array}{l}\text { Single } \\
\text { bubble }\end{array}$} & transient & $\begin{array}{l}\text { skin, muscle, bone, } \\
\text { brain, }\end{array}$ & none \\
\hline & continuous & $\begin{array}{l}\text { skin, muscle, bone, } \\
\text { brain, }\end{array}$ & $\begin{array}{l}\text { bone wax } \\
\text { electrocoagulation }\end{array}$ \\
\hline \multicolumn{2}{|c|}{ Stormy bubble } & $\begin{array}{l}\text { muscle } \\
\text { dura }\end{array}$ & $\begin{array}{l}\text { reflection of dura } \\
\text { electrocoagulation } \\
\text { massive muscle suture }\end{array}$ \\
\hline
\end{tabular}

布，筋肉結禁などの手術操作を行うことが必要である。

Stormy bubble type を示守のは，笳肉上硬膜の手術操作 中に多くみられ，特に硬膜切開時の空気流入が強く，諸家 の1報告とも一致した。これは，硬膜の静脈注硬膜切開後 もその構造上 open vessel の状態を保ちやすいため，他の組 織より空気流入が多くなるものと考元られる。その対策と しては，硬膜断端上りの空気流入在防ぐためには，断端の 電気凝固を行ら上りも硬膜反転を行うほうが時間的にも早 く，また，容易に air bubbleの流入を防止することができ るので，まず硬膜を反転させたのちに断端の電気凝固を行 うべきである，筋肉断端からの空気流入量注症例比上り多 少の差があるものと考えられるが，多くは電気凝固や開創 器による筋肉压排によりコントロールすることができた， 同操作を行っても空気の流入が持続する場合は，massiveに 筋肉を結㮃することによって空気栓塞を防ぐことができ た。従来, 空気栓塞の予防として, 術野考生食水や wet cotton strips で覆うべきであると言われていたが，菊田らりる 効果が無かったと報告しているように, stormy bubble type の梀気の流入がみられたときに，術野を生食水とwet cotton stripsで覆ってみたが著明な効果はみられなかった。

Stormy bubble type の空気流入がみられたときに，術前 に挿入したスワンガンツカテーテルより空気の吸引を試み たが，ほ上んど吸引することはできなかった，Stormy bubble type の空気の流入が持続的にみられたときは，スワン ガンツカテーテル上り $2 \mathrm{~m} l$ から最高 $20 \mathrm{~m} l$ の空気の吸引が 行われた。もちろん，流入した空気がすべてスワンガンッ カテーテルより吸引される訳ではないが，緊急の処置とし ては有用であると考えている，空気吸引だけの目的には，

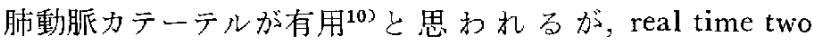
dimensional echocardiography を用いることにより空気栓 塞の早期発見が可能であるため，スワンガンツカテーテル の術後全身管理化対する有用性を考慮し，我々注肺動脈力 テーテルは用いず，スワンガンツカテーテルを使用してい
る。連続的にみられる stormy bubble type や，連続的 air bubbleの流入のみら机る場合は，カテーテルを用いて流入 した空気を吸引寸ることはほとんど効果がないことがわか った.

空気栓塞に対する麻醉科的処置としては ${ }^{12,18)}$ ，両側顠部 静脈の压迫, 人工呼吸器による PEEP' ${ }^{8}$ の使用, antigravity suit の使用 ${ }^{11}$ ，純酸素の吸入 ${ }^{32}$ ，右房カテーテルよりの空 気の吸引 $)^{7}$ ，体位変換により，手術野を心睵より低位置に することなどが行われているが，満足すべき結果を得てい ること注ない，したがって今回我々が報告したように， 空気流入をすばやく発見し，手術操作によって空気流入を できるだけ早く防止して，大事に至らないようにするこ上 が重要である。

\section{$\mathrm{V}$ 結 語}

1. 坐位手術に招ける空気栓塞の発見に，超音波断層心 臓モニターを使用した。これは sensitivityが高く，流入 空気をただちに発見でき，他のモニターで検出しえない singlc air bubble でも検出可能であった。そのため空気流 入原因の検索を早期们行らことができ，手術手技によって 空気流入を予防できた，超音波断層心臟モニタ一はnon invasive な空気栓塞の発見法であり，videorecorder 併用 するこ上によって，流入した空気を客観的汇観察すること ができ，後日，詳細汇手術操作と空気流入の関係を検討で きた. Air bubble の流入の型には， single bubble type 上 stormy bubble type 上があり，臨床的に問題となるのは stormy bubble type であった.

2. 空気栓塞防止のための手術手技上して，従来術野を 生食水で覆うべきであると言われているが，実際にその効 果は少ない，硬膜よりの空気流入防止には，硬膜の反転が 有用であった。

3. 坐位手術にての空気流入は避けえないので，坐位手 術の適応は非常に綮密にするべきである。坐位手術を行う 場合には，超音波断曾心䁍モ二ター上 videorecorder 上の 併用モニタリングを含めた可能な限りのモニターを用い， 空気流入の早期発見，早期防止をすることが必要である。

な押，本論文の要旨忟，第39回日本媨神経外科学会総会(1980年 10月, 金沢)に招以て発表した.

\section{文献}

1) Cabezudu M, Gilsanz F, Vaguero J: Air embolism wound from a pin-type head-holder as a complication of posterior fossa surgery in the sitting position. $J$ Neurosurg 55: 147-148, 1981 
2) David H, Peter SS: Detection of venous air embolism. Anaesthesia 34: 578-582, 1979

3) Ebina $T$, Tanaka $M$, Kosaka $S$, Unno K, Terakawa $Y$ : Ultrasonotomography for the heart and great vessels. Jpn J Med Sci Biol 6: 16, 1967

4) English JB, Westenskow: Comparison of nervous air embolism monitoring in supine dog. Anesthesiology 48: 425, 1978

5) Jacob F: Treatment of air embolism. JAMA 241: 1681,1979

6) James AS Jr, David SL, Wade HR: Pulmonary edema following air embolism. Anesthesiology 40: 194-196, 1974

7)菊田 勇, 安達 莧, 竹原好文：座位手術時の整気栓塞 の治療，麻酔XXVIII : 1070-1075, 1979

8) Maravchick S, Delisler E, Welch F: The use of PEEP to identify the sourse of cardiopulmonary air embolism. Anesthesiology 49: 294-295, 1974

9) Maroon JC, Codman JM, Horner TG, Cambell RL: Detection of minute venous air embolism with ultrasound. Surg Gynecol Obstet 127: 1236-1238, 1968

10) Marshall WK, Bedford RT: Lise of a pulmonary artery catheter for detection and treatment of nervous air embolism. Anesthesiology 52: 131-134, 1980

11) Martin JT: Neuroanesthetic adjunct 1, 2. Anesth Analg (Cleve) 49: 577-593, 1970

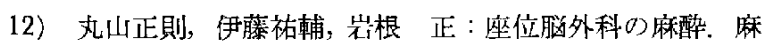
酔XXIV: 825-831, 1975

13) Maurice SA: Intracardiac catheters in neurosurgical anesthesia. Anesthesiology 50:50-67, 1979

14) Michenfelter JD, Martin JT, Altenburg BM, REhder $\mathrm{K}$ : Air embolism during neurosurgery. JAMA 28: 13531358,1968

15) Phillipa N, Albin MS, Chestnut JS: Air embolism during trans-sphenoidal pituitary operation. Neurosurgery 2: 39-41, 1978

16) Philip LG, Obrien RP, Britt WJ: The efficacy of Doppler monitoring for the detection of venous air embolism. $J$ Neurosurg 54: 75-78, 1981

17) Smith C: An end-oesophageal sthethoscope. Anesthesiology 15: 566,1954

18）立石春広，古川哲二：座位手術と空気栓塞. 麻醉XXII： $1-10,1972$

19) Wilkins RH, Albin MS: Unusual entrance site of venous air embolism during operations in the sitting position. Surg Neurol $7: 71-73,1977$

〔別刷請求先：干160 東京都新宿区信濃町35, 慶応義塾大学 脑神経外科，传藤周三] 